\title{
The influence of the Polish financial supervision authority on the bank's management board
}

\author{
Beata GRODZISKA-MODZELEWSKA \\ University of Wroclaw, Poland
}

Received: 25.08.2020, Revised: 19.10.2020, Accepted: 07.01.2021

doi: http://dx.doi.org/10.29015/cerem.884

\begin{abstract}
:
Aim: The aim of the article is to analyze the supervisory measures available to the Polish Financial Supervision Authority in relation to the management board of banks operating in Poland and to indicate whether these measures have a real impact on their functioning and internal structure. On this basis, the proposed changes for the Polish supervision model will be indicated. The article is to be the basis for a discussion on the actual possibilities of supervisory authorities in individual European countries.
\end{abstract}

Design/ Research methods: dogmatic and legal method, reflection on the Polish banking law, Polish and foreign legal literature.

Conclusions/findings: The analysis of the indicated subject matter led to the conclusion that the possibility of using measures of an imperative nature is an element included in the concept of the Polish Financial Supervision Authority as a public administration body. Despite the powers vested in it, each time there must always be premises for the supervisory authority to apply certain sanctions to members of the bank's management board. Therefore, the Polish Financial Supervision Authority is not fully independent.

Originality/ value of the article: The article is of value for legislative bodies, it indicates de lege ferenda postulates that should be applied for the Polish Financial Supervision Authority to be independent in the field of supervision over bank management boards.

Implications of the research: The changes to the Polish banking law are necessary for the Polish Financial Supervision Authority to be able to exercise actual supervision, especially within the banking segment.

Keywords: Polish Financial Supervision Authority, Public Administration Body, bank body, The bank's management board, resources ad rem, ad personam measures, Art. 138 of the Polish Banking Act

JEL: K, K2, K23

\footnotetext{
Correspondence address: Beata GRODZISKA, Doctoral School of the University of Wrocław, Faculty of Law, Administration and Economics, ORCID: 0000-0001-7240-5291. E-mail: beatagrodziska@gmail.com
} 


\section{Beata GRODZISKA-MODZELEWSKA}

\section{Introduction}

The crisis in 2007 and 2008 exposed inadequate legal regulation of financial supervision, both domestically and globally. However, it led to a gradual unification of legal regulations concerning the financial market in the EU member states. As a consequence, inter alia an integrated supervision model has been introduced in Poland, Germany and Great Britain (International Monetary Fund 2009). According to the concept of integrated supervision, supervisory authorities should be independent in terms of decisions made.

The financial market is most often defined as all transactions related to the movement of money capital from entities with free financial resources to entities that need such funds (Bień 2003: 5). Supervision over the financial market plays an important role. Its correct regulation determines the efficiency and safety of all trading participants, which in turn affects the proper development of the economy (Jurkowska- Zeidler 2016: 14). The lack of appropriate regulations may lead to financial market participants taking actions that are unlawful and violate the principles of the Banking Act (Kaszubski 2006: 57-62).

Banking activity is a type of economic activity that is strictly regulated. Depending on the country, supervision over this segment is performed by specialized supervisory authorities with different supervisory powers (Lastra 1996: 25-30).

In Poland, since 2006, supervision over the financial market has been exercised by a specially appointed public administration body, is the Polish Financial Supervision Authority (Wiktorzak 2014: 88-90). It was equipped with supervisory powers to eliminate the emergence of both crisis situations and illegal activities in the area of, inter alia, banking, pension, insurance and capital sectors (Szumlakowski 2011: 54-60).

Establishing the PFSA is tantamount to adopting the model of uniform supervision over the financial market in Poland. Supervisory powers over the banking system, as well as the powers and means of implementing them, which the Polish Financial Supervision Authority has been equipped with from the Act of July 21, 2006 on Financial Market Supervision and the Act of August 29, 1997, The 
Banking Act, which regulate the specific nature of the activities of this authority. These regulations are not exhaustive as they contain references to other national laws and legal acts of the European Union. However, they constitute the legal basis for supervision, among others over the banking system. The purpose of supervision over the financial market, pursuant to Article 2 (the act on supervision over the financial market) is to ensure the proper functioning of this market, its stability, security and transparency, trust in the financial market, as well as to ensure the protection of the interests of market participants through the implementation of objectives defined (Hawkesby 2000: 118), inter alia, in the Banking Act, the act of 22 May 2003 on insurance and pension supervision, the act of 15 April 2005 on supplementary supervision over credit institutions, insurance companies, reinsurance companies and investment companies being part of a financial conglomerate, the act on July 29, 2005 on supervision over the capital market, the act of November 5, 2009 on cooperative savings and credit unions and the act of August 19, 2011 on payment services (Fojcik-Mastalska 2007). Therefore, the PFSA performs a license, supervisory and regulatory function (Głuchowski 2010: 145). The supervision exercised by this authority can be divided into preventive and repressive.

In view of the above, the question is whether the banking supervisor has a real influence on the bank's management? After the analysis, it is necessary to indicate possible proposals for changes in the scope of its activity.

\section{Bank authorities}

The legal definition of the concept of a bank is contained in Article 2 the Banking Act. stating that the bank is a legal person established in accordance with the provisions of the acts, operating on the basis of authorizations authorizing the performance of banking activities involving risk, funds entrusted under any repayable title. It should be emphasized that, contrary to popular belief, the bank is not a financial institution, nor is it a unit of the public finance sector, which results from Article 9 point 14 of the Public Finance Act. It is a legal person (Srokosz 2000: 45-48). The issue of risk is inextricably linked with the concept of a bank. An 


\section{Beata GRODZISKA-MODZELEWSKA}

important feature of a bank is that it does not have any funds of its own, as most of the funds it has have been entrusted to it by trading participants.

The Banking Act distinguishes a closed catalog of legal and organizational forms available to banks, namely: a state bank, a cooperative bank and banks in the form of joint stock companies. The main difference between these banks lies in the different method of establishment and the different status of these legal entities. It should be pointed out that the Banking Act divides regulations concerning only state-owned banks (Articles 14-19), cooperative banks (Articles 20-20a) and banks in the form of joint-stock companies (Articles 21-28) (Wiktorzak 2014: 42-46).

Each bank, being a legal person, operates through its authorities in the manner provided for in the Act and in the statute based on it (Article 38 of the Civil Code). Members of the bank's governing bodies should have such qualities as: knowledge, skills, experience appropriate to the functions they perform and the duties entrusted to them, and should guarantee the proper performance of their duties. The attributes that characterize members of the bank's management board and supervisory board are general clauses, and consequently, there is no legal definition of these terms. If the PFSA decides that the candidate does not deserve approval, then he is excluded from applying for the position.

Situations in which the PFSA may not accept the candidacy of a specific person have been exhaustively regulated by the legislator in Article 22b paragraph 3 the Banking Act.

\subsection{State bank}

A state-owned bank may be established by the Council of Ministers by regulation. In the same way, it is liquidated. Both the establishment of this bank and its liquidation must be expressed by the PFSA. The authorities of a state-owned bank are the management board and the supervisory board. Their members may not conduct competitive activities, e.g. be members of the governing bodies of other banks, except where a state-owned bank is a shareholder of that bank. The term of office of the supervisory board is 3 years. Its chairman is appointed and dismissed by the Prime Minister. In turn, the members of the supervisory board are appointed by the Prime Minister from persons who are not members of the bank's management 
board. The president of the management board is appointed and dismissed by the supervisory board. On the other hand, the remaining members are appointed and dismissed at the request of the president of the management board by the supervisory board. The appointment of the president of the management board and one member of the management board takes place with the consent of the Polish Financial Supervision Authority (Czerniawski 2013c: 1-3). The supervisory board of a state bank exercises general supervision, gives recommendations to the management board of the bank and suspends members of the management board from performing their duties. The influence of the supervisory board on the bank's management board is visible because it may repeal its resolutions in the event of finding them inconsistent with the law or the bank's statute. The president of the management board of a state bank is its representative, organizer of its activities and presides over the management board (Szczęsny 2004: 15-17).

\subsection{Cooperative bank}

According to the statutory regulation, a cooperative bank is a cooperative to which, in the scope not regulated by the Banking Act, the Cooperative Law Act applies. The articles of association of this bank are drawn up in the form of a notarial deed. The founders of a cooperative bank may be at least 10 natural persons. The function of the supervisory body is performed by the supervisory board consisting of at least 5 persons. Its members are appointed and dismissed by the general meeting, taking into account, inter alia, their knowledge, skills. The management board of a cooperative bank consists of at least three persons appointed by the supervisory board. The supervisory board informs the PFSA about appointing or changing the management board.

The work of the management board is managed by its president. The difference between a state-owned bank and a cooperative bank is that the management board of the bank in question has a separate position of a member or members of the management board who deal with the management of risks relevant to the bank's operations. The bank's management board determines the internal division of powers in the bank's management board, which is then approved by the supervisory board. The purpose of the division of competences in the bank's management board 


\section{Beata GRODZISKA-MODZELEWSKA}

is transparency and organization of the internal structure. The president of the management board of a cooperative bank is appointed with the consent of the Polish Financial Supervision Authority, requested by the supervisory board. First of all, it should be noted that the PFSA has an influence on the bodies of the cooperative bank already at the stage of their appointment, because the PFSA agrees to appoint members of the management board.

This is a personal right. It should be pointed out that there is a dichotomous division between the members of the management board. It manifests itself in the fact that the members of the management board are divided into those whose appointment the PSFA had to consent to and those who did not have to obtain such consent. In the provision of article 22d the Banking Act specific persons have been indicated who must obtain the consent of the Polish Financial Supervision Authority. The other members do not need the approval of the Polish Financial Supervision Authority. The legislator also does not indicate a specific number of members who must have such consent. According to Article 17 of the Banking Act the appointment of the president of the management board and one member of the management board shall be made with the consent of the Polish Financial Supervision Authority. The provisions of Article 22b shall apply accordingly (Gonnet 2010: 31-41). Moreover, each cooperative is obliged to undergo a lustration examination of the legality, economy and reliability of its entire operation at least once every three years, and during the period of being in liquidation. Vetting covers the period from the previous vetting (Article $91 \S 1$ of the Cooperative Law).

\subsection{A bank in the form of a joint stock company}

The regulation of the bank's bodies in the form of a joint stock company is analogous to that of a cooperative bank (Kidyba 2010: 34-48). The difference is that the founders of a bank in the form of a joint-stock company may be legal and natural persons, but there can be no fewer than 3. It is important that the provisions of the Commercial Companies Code apply to a bank in the form of a joint-stock company, o how many regulations of the Banking Act do not state otherwise (Bajor 2001: 34). According to Article 370 of the Commercial Companies Code, a member of the management board may be recalled at any time, however, the company's articles of 
association may contain other provisions, in particular limiting the right to appeal to important reasons (see Table 1).

Table 1. Main differences between banks

\begin{tabular}{|l|l|l|l|}
\hline Type of bank & State bank & Cooperative bank & $\begin{array}{l}\text { Bank in the form of a } \\
\text { joint stock company }\end{array}$ \\
\hline $\begin{array}{l}\text { The way of } \\
\text { creating }\end{array}$ & Council of Minister & Form of notarial deed & Form of notarial deed \\
\hline Bank bodies & $\begin{array}{l}\text { Management board, } \\
\text { supervisory board }\end{array}$ & $\begin{array}{l}\text { Supervisory board, } \\
\text { consisting of at least 5 } \\
\text { people }\end{array}$ & $\begin{array}{l}\text { Just like a cooperative } \\
\text { bank }\end{array}$ \\
\hline $\begin{array}{l}\text { Special } \\
\text { features }\end{array}$ & $\begin{array}{l}\text { The term of office } \\
\text { of the supervisory } \\
\text { board is } 3 \text { years, } \\
\text { the chairman is } \\
\text { appointed by the } \\
\text { Prime Minister } \\
\text { individuals, } \\
\text { specially appointed } \\
\text { member of the } \\
\text { management board } \\
\text { responsible for } \\
\text { managing the risk of } \\
\text { significant bank } \\
\text { operations }\end{array}$ & $\begin{array}{l}\text { The founder of this } \\
\text { bank may be at least 3 } \\
\text { natural and legal } \\
\text { persons }\end{array}$ \\
\hline
\end{tabular}

Source: author's own elaboration based on Kidyba (2010) and Bajor (2001).

\section{Supervisory measures implemented in relation to the bank's management board}

As indicated, the PFSA has an influence on the bank's authorities already at the stage of their appointment. The supervisory measures granted to the PFSA have been ranked from the least invasive to the most interfering in the bank's activities (this gradation results directly from the statutory regulation). These resources are broken down into ad personam and ad rem surveillance measures. From the point of view of the research assumptions of this study, only ad personam supervisory sanctions are relevant, as they directly apply to members of the bank's management board, and thus constitute the implementation of the supervisory powers of the 
PFSA over this bank's body. The ad personam measures include: applying to the competent body of the bank to dismiss the president, vice-president or another member of the bank's management board directly responsible for the irregularities found, suspension of the members of the management board until a resolution is adopted on the motion for their dismissal by the supervisory board at the next meeting, dismissal of a member of the bank's management board in the event of a final conviction for an intentional offense or fiscal offense, the possibility of imposing a fine on a member of the bank's management board (Ofiarski 2013: 12$16)$.

\subsection{Dismissing a member of the management board}

Each supervision measure is a form of interference by a public administration body in the internal sphere of the bank being a legal person. There are no prohibitions resulting from the Banking Act and other acts regulating the activities of the PFSA regarding the cumulative application of supervisory measures and supervisory sanctions. The right to dismiss a member of the management board results from Article $138 \mathrm{sec} .3$ point 1 of the Banking Act stating that the PFSA may apply to the competent authority of the bank to dismiss the president, vice-president or another member of the bank's management board who is directly responsible for the irregularities found. The indicated legal basis lists specific persons who may be dismissed by the PFSA, namely: president, vice president, member of the management board directly responsible for the infringement found. There is ambiguity regarding the understanding of the term of the management board member directly responsible for the infringement. The directly responsible member must commit the infringement on his own so that he can be accused of reprehensible action. Thus, the legislator divided the members of the management board into: directly responsible, indirectly responsible and not bearing such responsibility for the infringement. The negative action should, in principle, be demonstrated by the PFSA in a formal application to the bank by referring to the infringement, its characteristics and indication of the person who committed it (Czerniawski 2013b: 4). 
The statement referred to above means a letter containing two formal requirements, i.e. the identification of the entity that committed the infringement and an indication of the infringement. The member of the body of the bank concerned cannot object to the request of the PFSA, lodge an appeal or make other appeals. It is a construction that cannot be appealed against. An application by the PFSA to the bank's competent authority is not binding, as it is solely up to the bank's supervisory board whether or not a member is dismissed. The PFSA's speech is a kind of preliminary stage consisting in the initiation of proceedings on the dismissal of an indicated management board member. It is the duty of the supervisory board to undertake checking activities. This obligation does not arise directly from a specific provision of the Act bank, but from all provisions regulating the duties of the supervisory board (e.g. Articles 16, 22aa The Banking Act, 219 Commercial Companies Code). Therefore, it is not possible to leave the Commission's proposal without consideration. After the supervisory board has analyzed the indicated violation, it may disregard the motion for dismissal, then it does not have negative consequences for the member of the management board. If the supervisory board finds any irregularities committed by a member of the management board, it decides to dismiss him. In correlation with the regulation in question, Article 138 sec. 3 point 2 the Banking Act, which will be discussed later in the article.

With article $138 \mathrm{sec} .5$ the Banking Act the obligation of the PFSA to dismiss a member of the management board in the event of a final conviction for an intentional crime or for a fiscal offense, with the exception of offenses prosecuted on a private prosecution, as well as in the case of failure to inform the PFSA of the charges being presented to him in criminal proceedings within 30 days from the date of the charges. As a rule, the PFSA decides on the type of supervisory sanction it intends to apply. However, in the indicated article there is an exception in the form of the obligatory obligation of the PFSA by the legislator to use the supervision sanctions. Therefore, in this case, in the event of a legally valid conviction and failure of the management board member to provide information to the PFSA, this authority must dismiss the management board member. This is an obligation arising directly from the provision cited. 


\section{Beata GRODZISKA-MODZELEWSKA}

Another possibility to dismiss a member of the management board is provided for in article 22d the Banking Act. It stipulates that in the event that a member of the supervisory board or the management board of the bank does not meet the requirements specified in Article 22aa, the Polish Financial Supervision Authority may request the competent authority of the bank to revoke it. This is another possibility for the Commission to apply to the competent authority of the bank when a member does not have, in the opinion of the Polish Financial Supervision Authority, sufficient knowledge or skills, for example. The Commission may initiate proceedings to dismiss a member. The initiation of such proceedings is optional (Czerniawski 2013a: 8-13).

\subsection{Suspension of a member of the management board}

Another ad personam supervisory measure in the form of suspension of a management board member is regulated in Article 138 sec. 3 point 2 the Banking Act. It is a power of the PFSA which it can exercise on a discretionary basis. As indicated, this regulation is closely related to Article $138 \mathrm{sec} .3$ point 1 of the Banking Act Suspension of activities consists in excluding the bank from making decisions with regard to its property rights and obligations. It enables the PFSA to act in two ways (on the one hand, it initiates the appeal procedure and suspends the activity of a management board member). Please note that the suspension concerns the scope of property rights and obligations. Thus, on the basis of a contrario inference, a suspended member may decide on the bank's non-property matters.

Article 138 sec. 4 the Banking Act introduces another option of the Polish Financial Supervision Authority to suspend a member of the management board in the event that he is presented with charges in criminal proceedings or in proceedings for a fiscal offense (first premise), or in the event of causing significant financial losses to the bank (second premise). It should be emphasized that these premises do not have to be cumulative. It should also be noted that in the case of the first premise, the ruling in question must be final for the suspension of the management board member to be effective. On the other hand, there is no legal definition of the concept of a significant property loss. According to Article $115 \S 5$ of the Criminal Code, property of considerable value is property, the value of which at the time of 
committing the prohibited act exceeds PLN 200,000. The above-mentioned article of the Criminal Code cannot apply in this case, because it defines the property of significant value, and not the property indicated in The Banking Act significant loss of property. This concept should be defined by the PFSA itself, taking into account the circumstances of the loss suffered and its size in relation to a specific breach.

There shall be no equality sign between the suspension and the dismissal of a member of the management board. These are two different concepts. Suspension is understood in Judicature and doctrine as a state of transition, temporary cessation of certain activities. The suspended member of the management board still has the status of a member of the management board, but is excluded from making decisions in the scope of the bank's property activity.

In turn, dismissal means cessation of the previous function on a permanent basis. The dismissal is also a more intrusive method compared to the suspension in terms of its effects on the member of the management board concerned. As it results from the above considerations, the premises of the discussed institutions are not the same, which leads to the conclusion that there is no competition between them. Therefore, if the Commission suspends a member, there is no possibility to dismiss him.

\subsection{Cash penalty}

Ad personam measures also include imposing fines by the PFSA on members of the management board in the event of failure to comply with the recommendations regarding the conduct of business in breach of the provisions referred to in Article 138 sec. 3 the Banking Act, articles of association, refusal to provide explanations, information referred to in article 139 , or in the event of failure to comply with the obligations set out in Chapter $11 \mathrm{~b}$ (which constitutes the obligation to serve letters in the rehabilitation proceedings). The Polish Financial Supervision Authority may impose fines up to PLN 20,000,000 (Kawulski 2013: 21-25) on members of the bank's management board. This penalty is limited in time, as it cannot be imposed if more than 6 months have elapsed since the banking supervision obtained information about the act, or more than 2 years have elapsed since the act was performed. The imposition of a financial penalty by the PFSA on a management 
board member is made by way of an administrative decision, which results from Article 11 sec. 2 point 17 of the Banking Act. It is final and immediately enforceable. The member of the management board concerned may request reconsideration of the case and then bring a complaint to the administrative court (Skoczylas 2000: 3-8).

Therefore, it is assumed that the indicated penalty is of an administrative nature. The amount of the fine should depend, inter alia, on the seriousness of the infringement, the method and the reasons for it, and the PFSA should take into account the infringer's previous behavior (Goodhart 2010: 14).

\section{Concluding remarks}

The powers of the PFSA indicate that this body acts to protect mostly the interests of the community. The possibility of using measures of an imperative nature is an element that is part of the concept of a public administration body. This fact distinguishes this supervisory authority from other institutions. It is a public administration body competent in matters of supervision over the financial market, in other words, a regulatory body classified as the protection of the financial market, including the banking segment. The purpose of banking supervision is the interference by the supervisory authority in the sphere of banking activity pursuant to legal provisions aimed at ensuring their legal and safe operation (Głuchowski 2010: 26-20).

In the literature, the suspension and dismissal of a management board member are classified as ad personam sanctions with which the PFSA has been provided. In order to be able to use these measures, it is necessary to meet certain statutory conditions. As a rule, the use of a particular legal measure depends on the PFSA's discretion.

It is a public administration body competent in matters of financial market supervision, in other words a regulatory authority classified as protecting the financial market, including the banking segment. However, does this allow the 
banking system supervisory authority to have a real influence on the bank's management board?

In the event of an appeal, the bank's competent authority, i.e. the supervisory board, makes the decision on the appeal. The PFSA only initiates the process of a possible appeal, but it is not possible to appeal against a negative decision of the bank's body. It should be stated that the possibilities of influencing the bank's management board by the PFSA are significant, and the most important provision in this respect is Art. $138 \mathrm{sec} .5$ of the Banking Act, according to which the PFSA is obliged to dismiss a management board member in the event of his final conviction for a crime or tax offense and in a situation where the management board member fails to fulfill the information obligation towards the PFSA.

Then the PFSA is obliged to make a decision with the statutory content. In this case, the dismissal of a management board member does not depend on the will of the bank's competent authority, but only on the decision of the PFSA. Therefore, there are two options for dismissing a management board member - one is optional, the other is obligatory.

The PFSA is a public administration body whose supervisory powers over the banking sector are very broad, and hence their ad personam implementation measures as well. Undoubtedly, the supervisory powers of the PFSA can be said in relation to the bank's authorities. The provisions regulating this interference cannot therefore be included in the so-called dead provisions. They apply when certain conditions are met. In conclusion, the PFSA performs tasks and competences strictly defined by law and cannot take actions without a clear legal basis. The supervisory powers vested in the PFSA do not have a direct effect, because, as a rule, it is not only up to the committee to decide whether a management board member is dismissed or suspended. The effectiveness of individual supervisory sanctions also depends on the bank's competent authority, i.e. the supervisory board.

It should be emphasized that the analysis covered the supervisory capacity of the PFSA with regard to the management board of individual banks operating in Poland. It should be pointed out that the postulated independence of the PFSA raises doubts, because the supervisory authority alone is not able to influence the indicated bank authority on its own. Despite the fact that this body is to be fully independent, it is 


\section{Beata GRODZISKA-MODZELEWSKA}

only possible to indicate independence in functional terms. It should be postulated that in the future the legislator should make this body fully independent in view of the goals set for this body. The proposed changes consist in the appointment of another supervisory body, fully independent of the PFSA, whose main task would be to replace the supervisory board operating in individual banks in the scope of making decisions regarding, for example, dismissal or suspension of management board members. Then the postulated principle of autonomy would be fully met, as the second body not related to the bank in any way (as opposed to the supervisory board) would be responsible for making decisions in the scope of this body of the bank. The new supervisory authority would include 7 people with expertise in finance, economy and banking. They would be appointed by the President and could not be part of any other collegiate body (including the PFSA).

\section{References}

Bajor B. (2001), Spółka akcyjna jako forma prawonoorganizacyjna banku, "Studia Prawnicze”, no. 3-4.

Bień W. (2003), Rynek finansowy, Stowarzyszenie Księgowych w Polsce, Warszawa.

Czerniawski R. (2013a), W jakich sytuacjach KNF odmawia obligatoryjnie wyrażenia zgody na powołanie w skład zarządu danej osoby?, QA 188918.

Czerniawski R. (2013b), Środki nadzoru bankowego stosowane ad personam, LexisNexis, Warszawa.

Czerniawski R. (2013c), Rola KNF w procesie powoływania członków rady nadzorczej i zarządu banku, Dom Wydawniczy ABC, Warszawa.

Fojcik-Mastalska E. (2007), Prawo bankowe. Komentarz, vol. 5, LexisNexis, Warszawa.

Goodhart Ch. A. E. (2010) The changing role of central banks. Monetary and Economic Department, Basel, Switzerland.

Gonet W. (2010), Nadzór i kontrola w bankach spółdzielczych, SipLex, PPP 2010/6/31-41.

Głuchowski J. (2010), System prawa finansowego, Wolters Kluwer, Warszawa.

Hawkesby Ch. (2000), Central banks and supervisors. The question of institutional structure and responsibilities, in: Financial stability and central banks. Selected issues for financial safety nets and market discipline, Halme L., Hawkesby Ch., Healey J., Saapar I., Soussa F. (eds.), Bank of England, London.

International Monetary Fund (2009), Global Financial Stability Report. Responding to the financial crisis and measuring systemic risks, International Monetary Fund, Washington DC. 


\section{THE INFLUENCE OF THE POLISH FINANCIAL SUPERVISION AUTHORITY ...}

Jurkowska- Zeidler A., Olszak M. (2016), Prawo rynku finansowego, Wolters Kluwer, Warszawa.

Kaszubski W. (2006), Funkcjonalne źródła prawa bankowego publicznego, Wolters Kluwer, Warszawa.

Kawulski A. (2013), Prawo bankowe. Komentarz, LexisNexis, Warszawa.

Kidyba A. (ed.) (2010), Spółka akcyjna, Wolters Kluwer, Warszawa.

Lastra R.M. (1996), Central banking and banking regulation, Financial Markets Group, London School of Economics and Political Science, London.

Ofiarski Z. (2013), Prawo bankowe. Komentarz, Wolters Kluwer, Warszawa.

Paszkowski S. (2010), Charakter prawny upomnienia (art. 138 ust. 3 prawa bankowego). Uwagi de lege lata i de lege ferenda, SipLex, PPP 2010/12/90-102.

Skoczylas A. (2000), Sankcje nakładane na członków zarządu banku na podstawie art. 141 prawa bankowego jako przykład kary administracyjnej, "Prawo Bankowe”, no. 12, pp. 49-51.

Srokosz W. (2000), Pojęcie usług finansowych w regulacjach prawnych Unii Europejskiej, "Prawo Bankowe", no. 9, pp. 79-88.

Szczęsny R. (2004), Zarząd w spółkach kapitałowych, Kantor Wydawniczy Zakamycze, Zakamycze.

Szumlakowski R. (2011), Komisja Nadzoru Finansowego jako organ administracji publicznej nadzorujący sektor bankowy w Polsce, w: Nadzór nad rynkiem finansowym. Aktualne tendencje i problemy dyskusyjne, Fojcik-Mastalska E., Rutkowska-Tomaszewska E. (eds.), Wydawnictwo Uniwersytetu Wrocławskiego, Wrocław, pp. 113-124.

Wiktorzak A. (2014), Komisja Nadzoru Finansowego jako organ nadzoru nad instytucjami sektora bankowego, Wydawnictwo Uniwersytetu Śląskiego, Katowice.

\section{Legal acts}

Ustawa z dnia 23 kwietnia 1964 r. Kodeks cywilny (Act of 23 April 1964 on Civil Code), Official Journal 2019, item 1145.

Ustawa z dnia 16 września 1983 r. Prawo spółdzielcze (Act of 16 September 1983 on Cooperative Law), Official Journal 2020, item 275.

Ustawa z dnia 6 czerwca 1997 r. Kodeks karny (Act of 6 June 1997 on Penal Code), Official Journal 2019, item 1950.

Ustawa z dnia 29 sierpnia 1997 r. Prawo bankowe (Act of 29 August 1997 on The Banking Act), Official Journal 2019, item 2357.

Ustawa z dnia 15 września 2000 r., Kodeks spółek handlowych (Act of 15 September 2000 on Commercial Companies Code), Official Journal 2000, item 505. 


\section{Beata GRODZISKA-MODZELEWSKA}

Ustawa z dnia 21 lipca 2006 r. o nadzorze nad rynkiem finansowym (Act of 21 July 2006 on Supervision over the Financial Market), Official Journal 2020, item 180.

Ustawa z dnia 27 sierpnia 2009 r. Prawo finansów publicznych (Act of 27 August 2009 on Public Finance Law), Official Journal 2019, item 869. 